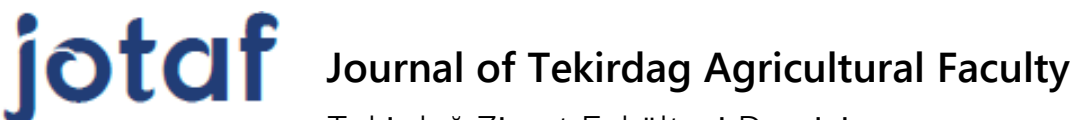

\section{Yield and Quality of Two Soybean Cultivars in Response to Drought and N Fertilization}

\author{
Oqba BASAL ${ }^{*}$, Dr. András SZABÓ ${ }^{2}$
}

\begin{abstract}
Applying mineral fertilizers is one way of re-fertilizing soils being exploited in agricultural production. However, fertilization quantity should be controlled and pre-evaluated, as excessive amounts have negative influence on both the plants and the soil. Drought stress has negative effects on both the quantity (yield) and the quality (seed content) of crops, especially drought-sensitive crops such as soybean; however, fertilization, if adequately applied, can partially ameliorate those negative effects. An experiment was conducted in Debrecen, Hungary in 2017 and 2018 to study the effects of nitrogen fertilization application under drought stress on the yield and the seed protein and oil concentrations of two soybean cultivars. Three $\mathrm{N}$ fertilization rates; 0,35 and $105 \mathrm{~kg} \mathrm{ha}^{-1}$ were applied under two irrigation regimes; Irrigated (control) and drought stressed (non-irrigated) regimes. Results showed that yield trait responded differently to fertilization and irrigation in the two cultivars. Protein concentration was enhanced by irrigation and by the high rate of N-fertilizer. Oil concentration decreased by irrigation and by high-rate fertilization under drought conditions, whereas increased by high-rate fertilization under irrigated regime. It was concluded that high rate of $\mathrm{N}$-fertilizer is not always recommended for the studied cultivars, especially when drought conditions are not present.
\end{abstract}

Key words irrigation; nitrogen; oil; protein; soybean

\footnotetext{
2*Sorumlu Yazar/Corresponding Author: Oqba BASAL, Institute of Crop Sciences, Faculty of Agricultural and Food Sciences and Environmental Management, University of Debrecen, 4032 Debrecen/Hungary E-mail: oqbabasal@gmail.com (iD OrcID: 0000-0003-2396-6591

${ }^{2}$ Andras Szabo Institute of Crop Sciences, Faculty of Agricultural and Food Sciences and Environmental Management, University of Debrecen, 4032 Debrecen/Hungary . E-mail: szabo@agr.unideb.hu (D) OrcID: 0000-0001-9397-1188

Attf/Citation: Basal, O., Szabo, A. 2020. Yield and quality of two soybean cultivars in response to drought and N fertilization.. Tekirdăg Ziraat Fakültesi Dergisi, 17(2), 203-210.

CBu çalışma Tekirdağ Namık Kemal Üniversitesi tarafından Creative Commons Lisansı (https://creativecommons.org/licenses/by-nc/4.0/) kapsamında yayınlanmıştır. Tekirdağ 2019
} 
Soybean (Glycine $\max$ (L.) Merrill) is the most seed legume grown globally; it is considered as a main source of vegetable protein and oil (Maleki et al., 2013; Mutava et al., 2015), and these two components are determined by the (genotype $*$ environment) interaction (Wilson, 2004). It is generally accepted that high yield in soybean is negatively correlated with protein concentration (Liang et al., 2010); moreover, oil and protein concentrations are usually negatively correlated (Chung et al., 2003).

Soybean yield is highly affected by drought stress (Fan et al., 2013; Li et al., 2013) which increasingly had occurred recently and, threatening world's food security (Vurukonda et al., 2016). Not only yield, but also seed quality of soybean is affected by drought (Vurukonda et al., 2016) because of soybean's high sensitivity to drought stress (Maleki et al., 2013). However, yield decrease-levels differ among genotypes (He et al., 2017). It was previously reported that drought stress reduced protein (Boydak et al., 2002; Carrera et al., 2009)and oil (Bellaloui and Mengistu, 2008; Rotundo and Westgate, 2009) concentrations, whereas other reports reported increased protein (Kumar et al., 2006; Wang and Frei, 2011) and oil concentration (e.g. Boydak et al., 2002; Specht et al., 2001); these differences were explained by different severities and/ortimings (stages) of drought stress applied (Carrera et al., 2009).

Nitrogen $(\mathrm{N})$ is majorly important for plant growth and yield; it is vital for many processes like chlorophyll and protein synthesis. Fageria and Baligar (2005) reported that $\mathrm{N}$ is very important for soybean vegetative growth and optimum biomass. The two main sources of $(\mathrm{N})$ for soybean plants are biologicallyfixed $\mathrm{N}_{2}$ and mineral (N) (Salvagiotti et al., 2008). $\mathrm{N}$ fertilization must be provided if a deficiency in fixed$\mathrm{N}_{2}$ occurs (Miransari, 2016), or else leaf- $\mathrm{N}$ will be remobilized to the seeds, leading to reduced photosynthesis and, eventually, reduced yield (Salvagiotti et al., 2008). N fertilization increases soybean drought tolerance by enhancing shoot nitrogen accumulation and shoot biomass (Purcell and King, 1996).

Our experiment aimed to determine the influence of applying different $\mathrm{N}$-fertilizer rates on the yield and the seed quality of two soybean cultivars under drought stress in comparison to irrigated control.

\section{Method}

Two soybean cultivars; 'Boglár' (00 maturity group) and 'Pannonia kincse' (I maturity group) (Bonafarm company, Hungary) were sown in the experimental site of Debrecen University (Látókép) (N. latitude $47^{\circ} 33^{\prime}$, E. longitude $21^{\circ} 27^{\prime}$ ) in 2017 and 2018 growing seasons. The soil type was calcareous chernozem, the precipitation amounts during the growing season of both years of study are shown in Figure 1, and the soil nutrient content is presented in Table 1.



Graph 1 Water amounts in drought-stressed (DS) and irrigated (I) regimes in 2017 (a) and 2018 (b). 
Table 1 Soil Nutrient Content in The Experimental Site.

\begin{tabular}{|c|c|c|c|c|c|}
\hline Soil Depth $(\mathrm{cm})$ & pH & $\mathrm{CaCO}_{3}(\%)$ & Total N (\%) & $\mathrm{PO}_{2} \mathrm{O}_{5}(\mathrm{ppm})$ & $\mathrm{K}_{2} \mathrm{O}(\mathrm{ppm})$ \\
\hline $0-25$ & 6.46 & 0 & 0.150 & 133.4 & 239.8 \\
\hline $25-50$ & 6.36 & 0 & 0.120 & 48.0 & 173.6 \\
\hline $50-75$ & 6.58 & 0 & 0.086 & 40.4 & 123.0 \\
\hline $75-100$ & 7.27 & 10.25 & 0.083 & 39.8 & 93.6 \\
\hline $100-130$ & 7.36 & 12.75 & 0.078 & 31.6 & 78.0 \\
\hline
\end{tabular}

Three N-fertilizer rates; 0, 35 and $105 \mathrm{~kg} \mathrm{ha}^{-1} \mathrm{~N}$ (using ammonium nitrate $\left.\mathrm{NH}_{4} \mathrm{NO}_{3}\right)(0 \mathrm{~N}, 35 \mathrm{~N}$ and $105 \mathrm{~N}$, respectively) were applied under two irrigation regimes; drought stress (DS) regime (where the precipitation was the only source of irrigation water) and irrigated (control) (I) regime (where an additional 80 and $100 \mathrm{~mm}$ of irrigation water was supplied in 2017 and 2018, respectively) (Fig. 1). The experimental design was split-split-plot design, with cultivars as the main plots, irrigation treatments as the sub-plots and fertilization treatments as the sub-sub plots. The final plot number was 48 plots $(2$ cultivars * 3 fertilization rates $* 2$ irrigation regimes $* 4$ replications). The dimensions of each plot were $9.2 * 5.4=49.68 \mathrm{~m}^{2}$ with 12 rows (45 $\mathrm{cm}$ row spacing) in each plot.

The yield was determined by harvesting the middle 4 rows of each plot. Both protein and oil concentrations were determined using NIR analyser Granolyser (Pfeuffer, Germany).

The analysis of variance (ANOVA) was conducted to compare the means of each treatment, and then tukey post-hoc test was conducted to indicate the statistically different means using SPSS (ver.25) software.

\section{Findings}

\section{Yield $\left(\mathrm{kg} \mathrm{ha}^{-1}\right)$}

For cultivar 'Pannonia Kincse', applying N fertilizer under drought stress conditions enhanced yield as compared to non-fertilized control;. When drought was waived off (I), $35 \mathrm{~N}$ insignificantly enhanced the yield, whereas $105 \mathrm{~N}$ resulted in reducing the yield by $3.1 \%$ relative to $35 \mathrm{~N}$; however, it was slightly higher than control (table 2).

On the other hand, irrigation resulted in better yield for $0 \mathrm{~N}$ and $35 \mathrm{~N}$ treatments compared to droughtstressed (DS) counterparts, whereas it slightly decreased yield for $105 \mathrm{~N}$ treatment. However, all differences were insignificant (table 2).

For cultivar 'Boglar', the high rate of $\mathrm{N}$ fertilizer measurably, yet not significantly, increased yield as compared to both $0 \mathrm{~N}$ and $35 \mathrm{~N}$ under drought stress conditions. On the contrary, $105 \mathrm{~N}$ treatment resulted in less yield compared to $0 \mathrm{~N}$ and $35 \mathrm{~N}$ treatments when drought was waived off, revealing that high $\mathrm{N}$ rate is not recommended for both cultivars under no-drought conditions (table 3 ).

Drought had more obvious negative influence on this cultivar; it significantly decreased yield by 33.5 and $33.9 \%$ in $0 \mathrm{~N}$ and $35 \mathrm{~N}$ treatments, respectively, and insignificantly decreased it by $12.0 \%$ in $105 \mathrm{~N}$ treatment (table 3).

\section{Protein Concentration $(\%)$}

Both cultivars responded similarly to $\mathrm{N}$ fertilization regardless of irrigation regime; applying $\mathrm{N}$ fertilizer in a small rate $(35 \mathrm{~N})$ resulted in decreasing protein concentration as compared to control treatments, 
however, this reduction was insignificant. On the other hand, the high rate $(105 \mathrm{~N})$ significantly increased protein concentration; the increase percentage in 'Pannonia Kincse' was $7.7 \%$ and $9.5 \%$ under drought stress regime, and $4.0 \%$ and $4.2 \%$ under irrigated regime compared to control and $35 \mathrm{~N}$ treatments, respectively, whereas for 'Boglar' it was $7.8 \%$ and $11.4 \%$ under drought stress regime and $2.7 \%$ and $3.0 \%$ under irrigated regime (tables 2 and 3 ).

Irrigation resulted in higher protein concentration for both cultivars, regardless of $\mathrm{N}$ application or rate. N35 treatment was significantly higher (by 5.6\% and 9.6\% for 'Pannonia Kincse' and 'Boglar', respectively) under irrigated regime compared to drought-stressed counterparts, whereas the increase of $105 \mathrm{~N}$ treatment was very slight and insignificant (tables 2 and 3 ).

\section{Oil Concentration (\%)}

Under drought stress regime, 35N treatment slightly increased oil concentration for 'Pannonia Kincse'; however, $105 \mathrm{~N}$ treatment significantly reduced it as compared to both $0 \mathrm{~N}$ and $35 \mathrm{~N}$ treatments. However, under irrigated regime $105 \mathrm{~N}$ treatment increased this trait relative to control and $35 \mathrm{~N}$ treatments, respectively (table 2).

'Boglar' followed one trend under both irrigation regimes; applying $\mathrm{N}$-fertilizer decreased oil concentration; moreover, $105 \mathrm{~N}$ treatment reduced oil concentration more than did $35 \mathrm{~N}$ treatment, and the reduction was significant under drought stress regime (by $3.4 \%$ as compared to control) but insignificant under irrigated regime (table 3).

For both cultivars, Irrigation reduced oil concentration regardless of $\mathrm{N}$ application or rate; however, the reduction was insignificant for $105 \mathrm{~N}$ treatment, whereas it was significant for both control and $35 \mathrm{~N}$ treatments (tables 2 and 3).

\section{Discussion}

Under both irrigation regimes, applying relatively-low rate of $\mathrm{N}$ fertilizer ( $\left.35 \mathrm{~kg} \mathrm{ha}^{-1}\right)$ to 'Pannonia Kincse' plants resulted in better yield as compared to the non-fertilized counterpart. Some researchers concluded that N-fertilizer addition increases yield (e.g. Norhayati et al., 1988; Takahashi et al., 1991) by reducing abortions of flowers and pods (Brevedan et al., 1978). However, a higher rate of $\mathrm{N}$ fertilizer resulted in higher yield as compared to the low N-rate only under drought conditions, whereas it resulted in yield reduction under well-watered treatment. It was previously reported that $\mathrm{N}$-fertilizer is very important under drought stress conditions (Obaton et al., 1982). Previously, Purcell and King (1996) concluded that the application of $\mathrm{N}$-fertilizer on soybean increased drought tolerance as it enhanced the accumulation of both shoot nitrogen and shoot biomass under drought stress conditions, whereas under well-watered conditions $\mathrm{N}$ application decreased yield to $2597 \mathrm{~kg} \mathrm{ha}^{-1}$ relative to $2728 \mathrm{~kg} \mathrm{ha}^{-1}$.

On the contrary, the same low rate resulted in lower yield as compared to control in 'Boglar' plants, however, the higher rate increased the yield under drought stress as compared to low-rate treatment, whereas it reduced the yield under well-watered treatment. Kaschuk et al. (2016) concluded that N-fertilizer did not lead to more yield of two different soybean cultivar groups (determinate and indeterminate) whether $\mathrm{N}$ application was at sowing time, during reproductive stages or both; it even resulted in a slight, insignificant yield loss when it was applied at full flowering stage. Previously, many researchers reported N-fertilizer application to reduce soybean yield (e.g. Hungria et al., 2006; Mendes et al., 2008). The reasons for alteration in the response to $\mathrm{N}$ among cultivars are not accurately specified; however, initial soil fertility, nodulation capacity, inoculant presence in soil and pre-sowing inoculation and the timing of $\mathrm{N}$ application all have a role (Gault et al., 1984; Peoples et al., 1995).

Apart from a slight, in significant increase in $105 \mathrm{~N}$ treatment in 'Pannonia Kincse', drought resulted in reducing the yield of both cultivars, regardless of $\mathrm{N}$ application or rate. Many papers reported soybean seed yield to be decreased under drought stress conditions (e.g. Sadeghipour and Abbasi, 2012; Li et al., 2013). Garcia et al. (2010) reported that genotypes significantly differ in yield production under drought stress conditions and also within the interaction between drought stress and genotype; similar conclusions were reported (Maleki et al., 2013; He et al., 2017); our results are consistent with this conclusion (Table 2). 
For both cultivars, the application of low $\mathrm{N}$ rate slightly reduced the protein concentration, whereas the higher rate significantly increased this trait, regardless of water availability. It was previously concluded that protein concentration increased when applied-N rate was increased (Bloom, 2006). N-fertilizer dose had a significant effect on seed protein concentration, as the dose of $\left(100 \mathrm{~kg} \mathrm{ha}^{-1}\right)$ increased seed protein just by $(2 \%)$, whereas the dose of $\left(200 \mathrm{~kg} \mathrm{ha}^{-1}\right)$ resulted in (14\%) increase in seed protein (Miransari, 2016). Rotundo and Westgate (2009) reported, in their meta-analysis study, that adding $\mathrm{N}$-fertilizer increased protein concentration by about $(8 \%)$ in field studies and by about $(27 \%)$ in all study environments.

Concerning oil concentration, 'Pannonia Kincse' responded differently to different $\mathrm{N}$ rates under the different irrigation regimes; under drought stress conditions it slightly increased and noticeably decreased with applying low and high rates of $\mathrm{N}$-fertilizer respectively, whereas it responded reversely under well-watered conditions. Boglar, on the other hand, followed one trend under both irrigation regimes; oil concentration was negatively correlated with $\mathrm{N}$ rate.

Regardless of $\mathrm{N}$ application or rate, drought stress resulted in reducing protein concentration. Few studies reported lower protein concentration (e.g. Boydak et al., 2002; Carrera et al., 2009) under drought stress conditions. Turner et al. (2005) reported a $24 \%$ decrease in seed protein concentration under stress conditions in chickpea plants; similar results were reported later on soybean by Rotundo and Westgate (2009) who demonstrated that water stress during the early reproductive stages resulted in a $16 \%$ decrease in seed protein.

Oil concentration of both cultivars responded similarly to drought stress, and in an opposite trend of protein concentration; drought stress increased oil concentration, regardless of $\mathrm{N}$ application and rate. Few reports showed increased oil content under water deficiency conditions (e.g. Boydak et al., 2002). Chung et al. (2003) reported soybean seed protein content to negatively correlate with the amount of seed oil, which supports our obtained results.

Table 2 Yield (kg ha-1), Protein Concentration (\%) and Oil Concentration (\%) of 'Pannonia Kincse' Soybean Cultivar under Three N-fertilizer Rates and Two Irrigation Regimes in Debrecen, Hungary

\begin{tabular}{|c|c|c|c|c|c|c|}
\hline \multirow[t]{2}{*}{ Trait } & \multirow{2}{*}{$\begin{array}{l}\text { Irrigation } \\
\text { Regime }\end{array}$} & \multicolumn{3}{|c|}{ Fertilization Rate $\left(\mathrm{kg} \mathrm{ha}^{-1}\right)$} & \multirow[t]{2}{*}{ LSD } & \multirow[t]{2}{*}{ CV $(\%)$} \\
\hline & & $0 \mathrm{~N}$ & $35 N$ & $105 \mathrm{~N}$ & & \\
\hline \multirow[t]{4}{*}{ Yield (Kg ha-1) } & DS & 4425 & 4460 & 4811 & 1010 & 13.37 \\
\hline & I & 4698 & 4894 & 4740 & 849 & \\
\hline & Average & 4562 & 4677 & 4776 & & \\
\hline & LSD & 620 & 1001 & 1179 & & \\
\hline \multirow{4}{*}{$\begin{array}{c}\text { Protein Concentration } \\
(\%)\end{array}$} & DS & $36.3^{\mathrm{b}}$ & $35.7^{\mathrm{b} 2}$ & $39.1^{\mathrm{a}}$ & 1.6 & 4.38 \\
\hline & I & $37.8^{\mathrm{b}}$ & $37.7^{\mathrm{b} 1}$ & $39.3^{\mathrm{a}}$ & 1.5 & \\
\hline & Average & 37.1 & 36.7 & 39.2 & & \\
\hline & LSD & 1.6 & 1.7 & 1.4 & & \\
\hline \multirow[t]{4}{*}{ Oil Concentration (\%) } & DS & $22.9^{\mathrm{a} 1}$ & $23.0^{\mathrm{a} 1}$ & $22.3^{\mathrm{b}}$ & 0.6 & 3.65 \\
\hline & I & $21.6^{2}$ & $21.4^{2}$ & 22.0 & 0.9 & \\
\hline & Average & 22.3 & 22.2 & 22.2 & & \\
\hline & LSD & 0.7 & 1.0 & 0.7 & & \\
\hline
\end{tabular}

- $\quad$ different letter indicates significant differences at .05 level among fertilization rates within certain irrigation regime.

- different number indicates significant differences at .05 level between irrigation regimes within certain fertilization rate. 
It could be concluded that soybean cultivars respond to drought stress differently in terms of both the yield and the seed quality. N-fertilizer application enhanced the yield under drought stress conditions, whereas it had low effect on 'Pannonia Kincse'plants under well-irrigated regime, moreover, high rate of N-fertilizer resulted in decreasing the yield under well-watered regime; however, it enhanced protein concentration under both irrigation regimes and oil concentration under irrigated regime. Irrigation enhanced protein concentration and decreased oil concentration. Whereas oil concentration decreased by irrigation and by high-rate fertilization under drought conditions.

Table 3 Yield (kg ha-1), Protein Concentration (\%) and Oil Concentration (\%) of 'Boglar' Soybean Cultivar under Three Nfertilizer Rates and Two Irrigation Regimes in Debrecen, Hungary

\begin{tabular}{|c|c|c|c|c|c|c|}
\hline \multirow[t]{2}{*}{ Trait } & \multirow{2}{*}{$\begin{array}{l}\text { Irrigation } \\
\text { Regime }\end{array}$} & \multicolumn{3}{|c|}{ Fertilization Rate $\left(\mathrm{kg} \mathrm{ha}^{-1}\right)$} & \multirow[t]{2}{*}{ LSD } & \multirow[t]{2}{*}{$\mathrm{CV}(\%)$} \\
\hline & & $0 \mathrm{~N}$ & $35 N$ & $105 \mathrm{~N}$ & & \\
\hline \multirow[t]{4}{*}{ Yield $\left(\mathrm{Kg} \mathrm{ha}^{-1}\right)$} & DS & $3677^{2}$ & $3648^{2}$ & 4037 & 781 & 16.03 \\
\hline & I & $4807^{1}$ & $4795^{1}$ & 4587 & 667 & \\
\hline & Average & 4242 & 4222 & 4312 & & \\
\hline & LSD & 791 & 662 & 785 & & \\
\hline \multirow{4}{*}{$\begin{array}{l}\text { Protein Concentration } \\
\qquad(\%)\end{array}$} & DS & $34.4^{\mathrm{b} 2}$ & $33.3^{\mathrm{b} 2}$ & $37.1^{\mathrm{a}}$ & 2.3 & 5.41 \\
\hline & I & $36.6^{\mathrm{b} 1}$ & $36.5^{\mathrm{b} 1}$ & $37.6^{\mathrm{a}}$ & 1.0 & \\
\hline & Average & 35.5 & 34.9 & 37.4 & & \\
\hline & LSD & 1.6 & 2.5 & 1.3 & & \\
\hline \multirow[t]{4}{*}{ Oil Concentration (\%) } & DS & $23.5^{\mathrm{a} 1}$ & $23.3^{\mathrm{a} 1}$ & $22.7^{\mathrm{b}}$ & 0.9 & 3.82 \\
\hline & I & $22.4^{2}$ & $22.1^{2}$ & 21.9 & 1.1 & \\
\hline & Average & 23.0 & 22.7 & 22.3 & & \\
\hline & LSD & 0.8 & 1.0 & 1.2 & & \\
\hline
\end{tabular}

- different letter indicates significant differences at .05 level among fertilization rates within certain irrigation regime.

- different number indicates significant differences at .05 level between irrigation regimes within certain fertilization rate.

\section{Acknowledgement}

The publication is supported by the EFOP-3.6.3-VEKOP-16-2017-00008 project. The project is cofinanced by the European Union and the European Social Fund. 


\section{Kaynakça/References}

Bellaloui, N., Mengistu, A. (2008). Seed composition is influenced by irrigation regimes and cultivar differences in soybean. Irrigation Science, 26(3), 261-268.

Bloom, A.J. (2006). Rising carbon dioxide concentrations and the future of crop production. Journal of the Science of Food and Agriculture, $86,1289-1291$

Boydak, E., Alpaslan, M., Hayta, M., Gerçek, S., Simsek, M. (2002). Seed composition of soybeans grown in the Harran Region of Turkey as affected by row spacing and irrigation. Journal of Agricultural and Food Chemistry, 50(16), 4718-4720.

Brevedan, R.E., Egli, D.B., Leggett, J.E. (1978). Influence of N nutrition on flower and pod abortion and yield of soybeans. Agronomy Journal, $70,81-84$.

Carrera, C., Martinez, M.J., DardanelliJ., Balzarini, M. (2009). Water deficit effect on the relationship between temperature during the seed fill period and soybean seed oil and protein concentrations. Crop Science, 49, 990-998.

Chung, J., Babka, H.L., Graef, G.L., Staswick, P.E., Lee, D.J., Cregan, P.B., Shoemaker, R.C., Specht, J.E. (2003). The seed protein, oil, and yield QTL on soybean linkage group I. Crop Science, 43(3), 1053-1067.

Fageria, N., Baligar, V. (2005). Enhancing nitrogen use efficiency in crop plants. Advances in Agronomy, 88, 97-185.

Fan, X.D., Wang, J.Q., Yang, N., Dong, Y.Y., Liu, L., Wang, F.W., Li, H.Y. (2013). Gene expression profiling of soybean leaves and roots under salt, saline-alkali and drought stress by high throughput Illumina sequencing. Gene, 512(2), 392-402.

Garcia y Garcia, A., Persson, T., Guerra, L.C., Hoogenboom, G. (2010). Response of soybean genotypes to different irrigation regimes in a humid region of the southeastern USA. Agricultural Water Management, 97(7), 981-987.

Gault, R.R., Chase, D.L., Banks, L.W., Brockwell, J. (1984). Remedial measures to salvage unnodulated soybean crops. Journal of the Australian Institute of Agricultural Science, 50, 244-246.

He, J., Du, Y.L., Wang, T., Turner, N.C., Yang, R.P., Jin, Y., Li, F.M. (2017). Conserved water use improves the yield performance of soybean (Glycine $\max (\mathrm{L}$.$) Merr.) under drought. Agricultural Water Management, 179, 236-245.$

Hungria, M., Franchini, J.C., Campo, R.J., Crispino, C.C., Moraes, J.Z., Sibaldelli, R.N.R., Mendes, I.C., Arihara, L. (2006). Nitrogen nutrition of soybean in Brazil: contributions of biological $\mathrm{N}_{2}$ fixation and $\mathrm{N}$ fertilizer to grain yield. Canadian Journal of Plant Sciences, 86, $927-$ 939

Kaschuk, G., Nogueira, M.A., De Luca, M.J., Hungria, M. (2016). Response of determinate and indeterminate soybean cultivars to basal and topdressing $\mathrm{N}$ fertilization compared to sole inoculation with Bradyrhizobium. Field Crops Research, 195, 21-27.

Kumar, V., Rani, A., Solanki, S., Hussain, S.M. (2006). Influence of growing environment on the biochemical composition and physical characteristics of soybean seed. Journal of Food Composition and Analysis, 19(2-3), 188-195.

Li, D., Liu, H., Qiao, Y., Wang, Y., Cai, Z., Dong, B., Liu, M. (2013). Effects of elevated CO2on the growth, seed yield, and water use efficiency of soybean (Glycine $\max$ (L.) Merr.) under drought stress. Agricultural Water Management, 129, 105-112.

Liang, H., Yu, Y., Wang, S., Yun, L., Wang, T., Wei, Y., Gong, P., Liu, X., Fang, X., Zhang, M. (2010). QTL Mapping of Isoflavone, Oil and Protein Contents in Soybean (Glycine max L. Merr.). Agricultural Sciences in China, 9, 1108-1116.

Maleki, A., Naderi, A., Naseri, R., Fathi, A., Bahamin, S., Maleki, R.(2013). PhysiologicalPerformance of Soybean Cultivars under Drought Stress. Bulletin of Environment,Pharmacology and Life Sciences, 2(6), 38-44.

Mendes, I.C., Reis-Junior, F.B., Hungria, M., Sousa, D.M.G., Campo, R.J. (2008). Adubacão nitrogenada suplementar tardia em soja cultivada em latossolos doCerrado. Pesq. Agropec. Bras. 43, 1053-1060.

Miransari, M. (2016). Soybeans, Stress, and Nutrients. in Mohammad Miransari (Eds.), Environmental Stresses in Soybean Production. Soybean Production Volume 2 (273-298). Chippenham: Nikki Levy.

Mutava, R.N., Prince, S.J.K., Syed, N.H., Song, L., Valliyodan, B., Chen, W., Nguyen, H.T. (2015). Understanding abiotic stress tolerance mechanisms in soybean: A comparativeevaluation of soybean response to drought and flooding stress. Plant Physiology andBiochemistry, $86,109-120$

Norhayati, M., Mohd Noor, S., Chong, K., Faizah, A.W., Herridge, D.F., Peoples, M.B., Bergersen, F.J. (1988). Adaptation of methods for evaluating N2 fixation in food legumes and legume cover crops. Plant and Soil, 108, 143-150.

Obaton, M., Miquel, M., Robin, P., Conejero, G., Domenach, A., Bardin, R. (1982). Influence du déficit hydrique sur l'activité nitrate réductase et nitrogénase chez le soja.Compte Rendue de Academie de Science 294 (serie III), 1007-1011. (in French).

Peoples, M.B., Herridge, D.F., Ladha, J.K. (1995). Biological nitrogen fixation: an efficient source of nitrogen for sustainable agricultural production? Plant and Soil, 174, 3-28.

Purcell, L.C., King, C.A. (1996). Drought and nitrogen source effects on nitrogen nutrition, seed growth, and yield in soybean. Journal of Plant Nutrition, 19(6), 969-993. 
Yield and quality of two soybean cultivars in response to drought and $\mathrm{N}$ fertilization Rotundo, J.L., Westgate, M.E. (2009). Meta-analysis of environmental effects on soybean seed composition. Field Crops Research, 110(2), $147-156$.

Sadeghipour, O., Abbasi, S. (2012). Soybean response to drought and seed inoculation. World Applied Sciences Journal, 17(1), 55-60.

Salvagiotti, F., Cassman, K.G., Specht, J.E., Walters, D.T., Weiss, A., Dobermann, A. (2008). Nitrogen uptake, fixation and response to fertilizer N in soybeans: A review. Field Crops Research, 108(1), 1-13.

Specht, J., Chase, K., Markwell, J., Germann, M., Lark, K., Graef, G., Macrander, M., Orf, J., Chung, J. (2001). Soybean response to water. Crop Science, 41, 493-509.

Takahashi, Y., Chinushi, T., Nagumo, Y., Nakano, T., Ohyama, T. (1991). Effect of deep placement of controlled release nitrogen fertilizer (coated urea) on growth, yield, and nitrogen fixation of soybean plants. Soil Science and Plant Nutrition, 37, $223-231$.

Turner, N.C., Davies, S.L., Plummer, J.A., Siddique, K.H.M. (2005). Seed Filling in Grain Legumes Under Water Deficits, with Emphasis on Chickpeas. Advances in Agronomy, 87, 211-250.

Vurukonda, S.S.K.P., Vardharajula, S., Shrivastava, M., SkZ, A. (2016). Enhancement of drought stress tolerance in crops by plant growth promoting rhizobacteria. Microbiological Research (Vol. 184). Elsevier GmbH.

Wang, Y., Frei, M. (2011). Stressed food - The impact of abiotic environmental stresses on crop quality. Agriculture, Ecosystems and Environment, 141(3-4), 271-286.

Wilson, R.F.(2004). Seed Composition. Soybeans: Improvement, Production and Users, ThirdEd. ASA, CSSA, SSSA, Madison, WI. 